\title{
Chapter 4 \\ The Bluefin Tuna Catch in the Strait of Gibraltar. A Review of Its History
}

\begin{abstract}
Taking bluefin tuna in the Strait of Gibraltar as a reference, a description is made of the fishing methods used in its capture from the ancient populations of hominids to the present day. To do so, and based on recent paleoanthropological studies, the hypothetical way in which this fish would have been caught by the neanderthals is described (over 30,000 years ago); based on an extensive bibliography on the subject, the way fishing would have taken place in the Roman city of Baelo Claudia (200 B.C.) is described; and how it was during the Modern Age and is nowadays. Information is given on the fishing statistics from three Spanish traps between 1525 and 1756, upon which different scientists have pronounced in recent publications, and emphasis is placed on the overfishing that has taken place since the middle of the 20th century, its consequences, and how these have been overcome.
\end{abstract}

\subsection{Over 30,000 Years Ago}

The caves of the Rock of Gibraltar offer much evidence of the presence of hominid populations, which have been studied since the mid-nineteenth century. An international group of scientists intensified digs from 1995 in the Gorham (Fig. 4.1) and Vanguard caves (Giles-Pacheco et al. 2001). The following phrase is taken from these studies: "En los últimos registros paleontológicos hemos detectado presencia de macro-ictiofauna identificable por vértebras de túnidos de medio y gran tamaño" (In the last paleontological records we have detected the presence of macro-ichthyofauna identifiable by tuna vertebrae of medium and large size). This undoubtedly refers to ABFT samples found in stratum III corresponding to the Magdalenian period (15,000 years ago) in the upper Paleolithic; although these caves are known to have been inhabited more than 40,000 years ago (Middle Paleolithic).

In later excavations (1999-2005; Fig. 4.2) in the Gorham cave (Finlayson et al. 2006) nodules of carbon have been found throughout stratum IV (20,000-30,000 years ago), which is associated with occupation by neanderthals, which in turn means that it was used by these hominids to make fires.

Stringer et al. (2008) discovered that the neanderthals that lived in these caves more than 30,000 years ago were already eating fish. Although consumption of ABFT 
4 The Bluefin Tuna Catch in the Strait of Gibraltar ...

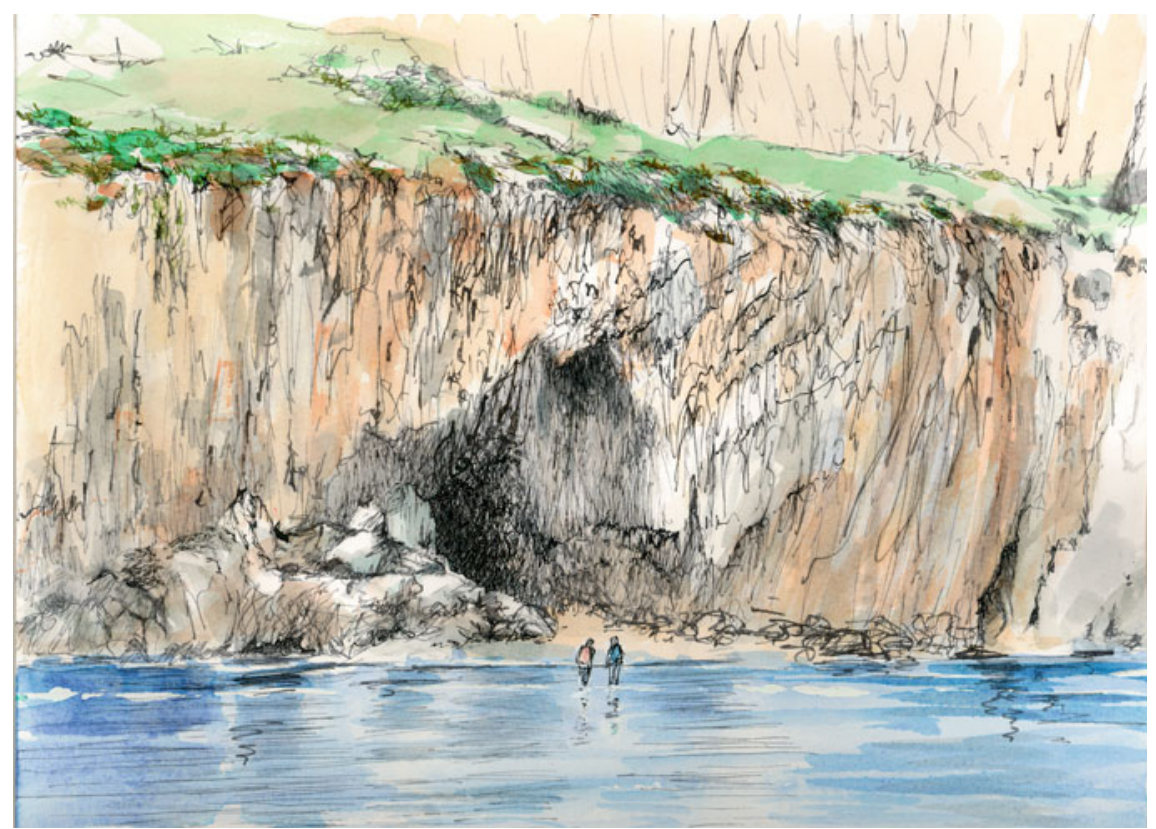

Fig. 4.1 Entrance to the Gorham cave (Gibraltar) Artist: Lineke Zubieta (Santander, Spain) (Documentary archive, $I E O$ )

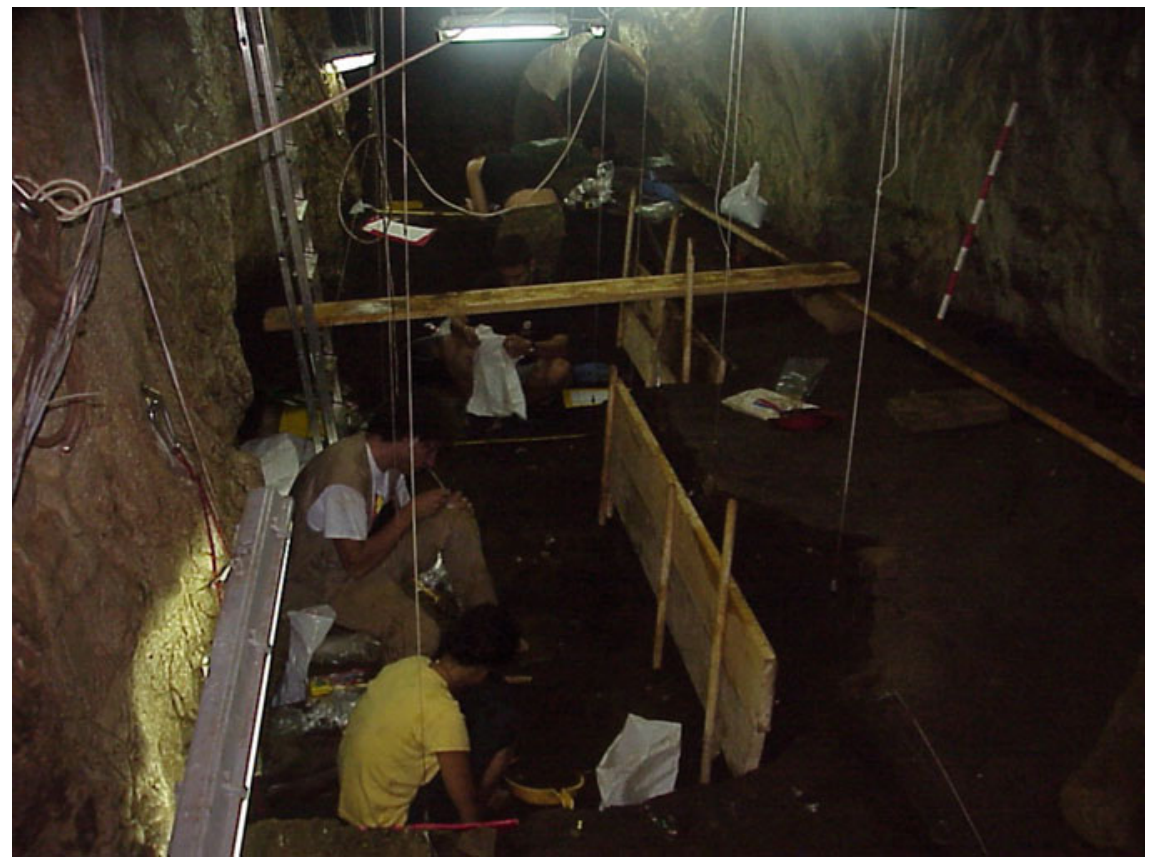

Fig. 4.2 Scientists excavating inside the Gorham cave (Courtesy of Francisco Giles Pacheco) 
by neanderthals is unproven, Cort (2006) cites the sporadic beaching of this species as a result of the stampedes produced in chases by killer whales, Orcinus orca (L.), as one of the possible ways in which hominids may have begun to eat it in addition to the small species found in the cave (Diplodus sargus (L.) or D. vulgaris (F.)). Such events are common on the beaches of the Strait of Gibraltar. The narrowness of the Strait of Gibraltar at that time $(10 \mathrm{~km})$, the lower sea level, $120 \mathrm{~m}$ below that of the present day (Allen et al. 1999; Tzedakis et al. 2002; Rodríguez-Vidal et al. 2013), with broad valleys (now underwater) and many islands (Montero and Bernal 2011), conditions may well have been favourable to beaching of tunas and other species.

The Strait of Gibraltar 30,000 years ago: from a cave on the edge of the broad plain the members of several neanderthal families descend on their way to the beach which, due to the present glaciation, is several kilometres away as a result of the 120-m fall in the sea level. It is spring, and as they know well from their predecessors, at this time of year the tunas, full of eggs, migrate eastwards. The strait now consists of two distinct broad channels and Africa is only $10 \mathrm{~km}$ away. The current is very strong, but the killer whales will soon begin the chase of the shoals of huge tunas. In the chase some of the enormous fishes will be beached, and each of them will ensure a lot of food for these last neanderthal families, who came here two thousand years earlier when they were fleeing from the glacial cold spreading through the European continent. Figures 4.3, 4.4 and 4.5 show three scenes that may have taken place in those times in the Strait of Gibraltar.

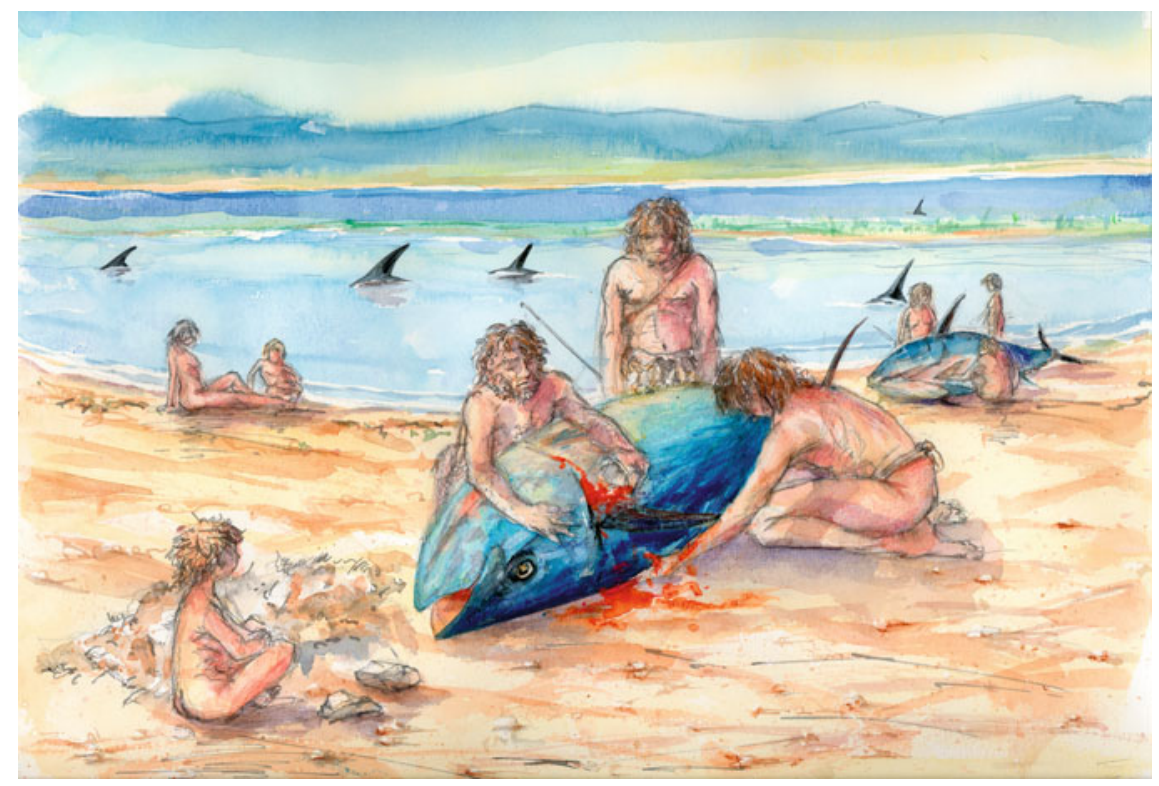

Fig. 4.3 Beached bluefin tuna being collected by the neanderthals in the Strait of Gibraltar 30,000 years ago An interpretation by Cort (2007) Artist: Lineke Zubieta (Santander, Spain) (Documentary archive, $I E O$ ) 


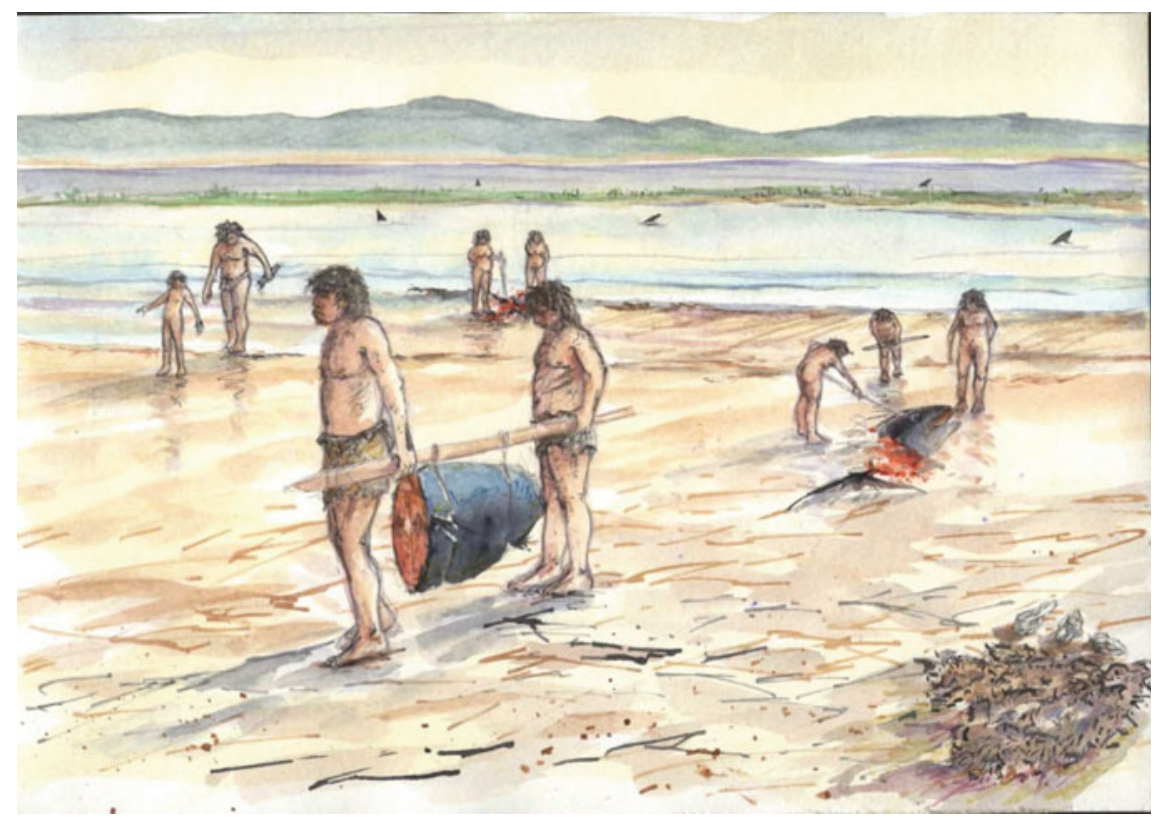

Fig. 4.4 Gutted bluefin tuna being transported to the cave An interpretation by Cort (2007) Artist: Lineke Zubieta (Santander, Spain) (Documentary archive, IEO)

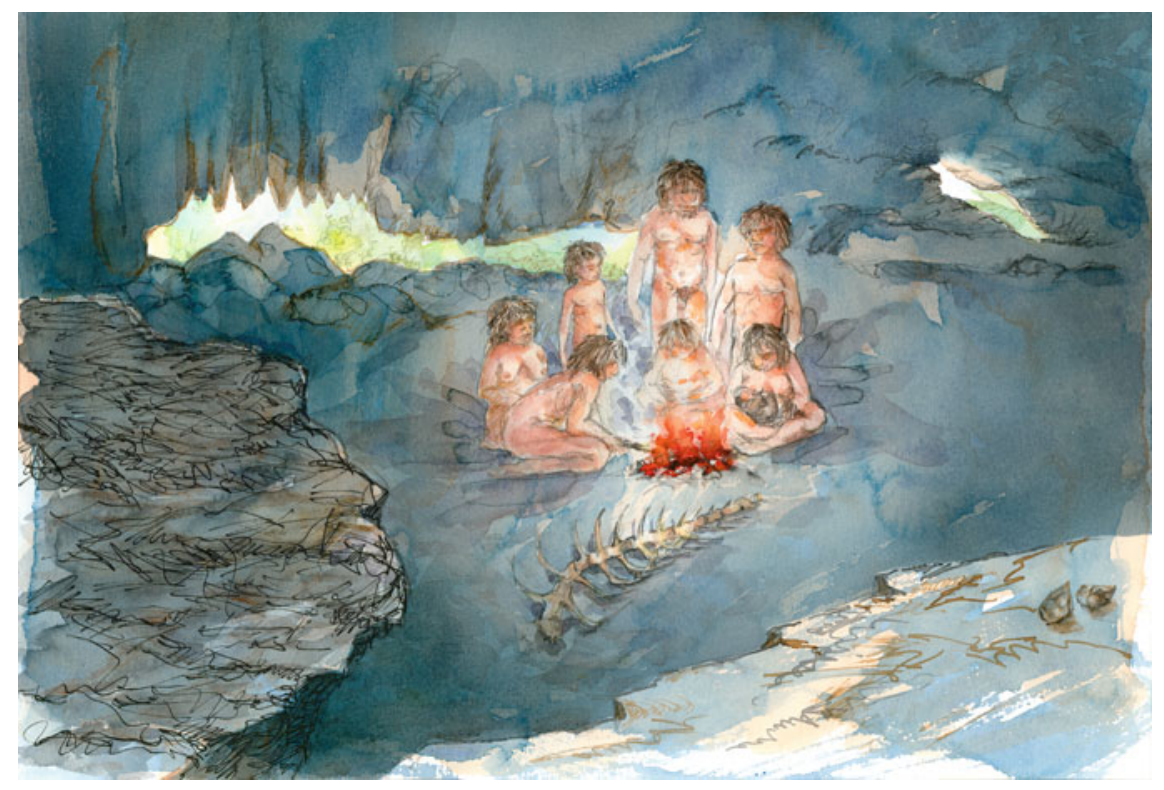

Fig. 4.5 Neanderthals feeding on bluefin tuna An interpretation by Cort (2007) Artist: Lineke Zubieta (Santander, Spain) (Documentary archive, IEO) 


\subsection{Phoenician-Roman Empire}

Many samples remain from the Phoenician and Roman empires (1200 BC-470 AD) both in the literature and the iconography of the interest and commerce arising from ABFT among coastal populations. Figure 4.6 shows the silhouettes of ABFT found in different regions (Sarà 1998).

For thousands of years bluefin tuna has been caught in the vicinity of the Strait of Gibraltar and throughout the Mediterranean basin (García Vargas and Florido del Corral 2011), but it was the Phoenicians who pioneered the use of nets which, over time, led to the traps, a fishing gear made up of labyrinths that was installed near the coast (Sarà 1998). Di Natale (2012) says: "trap fishery is the most ancient industrial activity in the fishery sector, because it is well known that "tuna traps" were operating in ancient times in Greece, and tuna traps were very active during Phoenician and Roman times, in many coastal areas".

During the Roman Empire ABFT formed the basis of considerable commerce both inside and outside the Mediterranean basin. The Roman city of Baelo Claudia was in the area of the Strait of Gibraltar (Arévalo and Bernal 2007; Fernández et al. 2007), situated in the inlet of Bolonia within what is now the Natural Park of the Strait just $12 \mathrm{~km}$ from the city of Tarifa in the province of Cádiz. The city was founded around the 3rd century $\mathrm{BC}$ and reached its height under the emperor Claudio (1st century BC), Fig. 4.7.

Fishing, the salting industry and production of garum (a sauce made from the leftovers of ABFT and other fishes macerated in the sun in brine) were the main sources of wealth in Baelo Claudia, a city from which exports were sent to the rest of the empire. García Vargas and Bernal (2009) provided plenty of information on the production of salted meats, fish sauces and commerce in the south of Hispania,
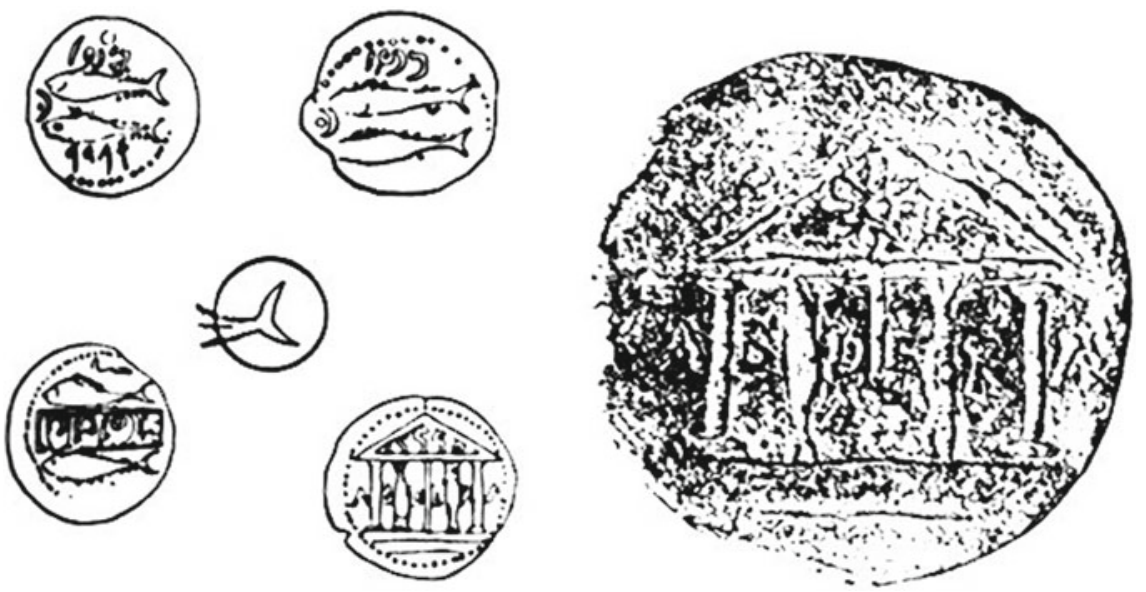

Fig. 4.6 Bluefin tuna on ancient coins. (From Ponsich, 1990. Taken from Sarà, 1998) 


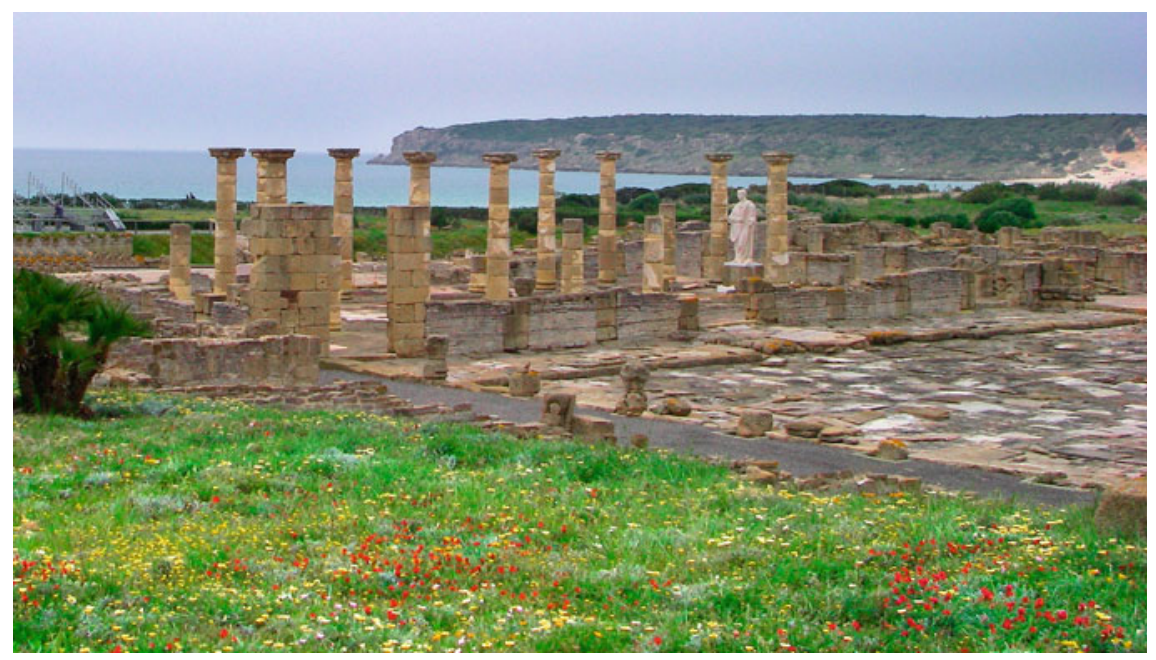

Fig. 4.7 Ruins of the Roman city of Baelo Claudia (Cádiz, Spain) (Courtesy of Kurt M. Schaefer)

which reflects the importance of ABFT in this industry. Morales and Roselló (2007) published the find of 683 ABFT vertebrae in a refuse tip of the Baelo Claudia factory in Punta del Caramiñal; and Niveau de Villedary $(2009,2011)$ even spoke of the meaning that ABFT might have had in the funeral ceremonies of those times, since vertebrae of this fish have been found in a grave pit with human remains (3rd century BC). Cort (2006, 2007), and García Vargas and Florido del Corral (2011) maintain that ABFT fishing in the Strait of Gibraltar in Roman times was conducted using nets thrown from boats. Other references to fishing for ABFT in the ancient world in the vicinity of the Strait of Gibraltar (Algarve, Portugal; Lixus, Morocco) are found in Ponsich (1988) and Aranegui (2008).

We find ourselves in the Roman city of Baelo Claudia in the proximity of the Strait of Gibraltar. The year is 195 BC and the bluefin tuna fishing season is well underway. The tuna spawning migration has long been known and the Romans have set up a fish factory here to catch tunas as they enter the Mediterranean Sea.

Everything is ready at the factory, and on the beach the fishermen await the moment. Soon afterwards, from the cape (Fig. 4.8) a look-out signals to them that it is time to put out the nets to intercept the approaching tunas (Fig. 4.9).

After several hours of work close to two hundred tunas have been caught, some of them with a weight of over $600 \mathrm{~kg}$ (Fig. 4.10).

At the end of the fishing operation the tunas are taken to the factory. Some of the meat from the tunas will be destined for the local population of Baelo Claudia, and the rest will be salted. The guts will be left to macerate and ferment in the sun in the factory to make garum. Garum was a gastronomic delicacy due to its organoleptic properties and it commanded a high price in the market. According to Plinio (23-79 AD), the historian and scientist, garum had a value comparable with the most expensive perfume. 


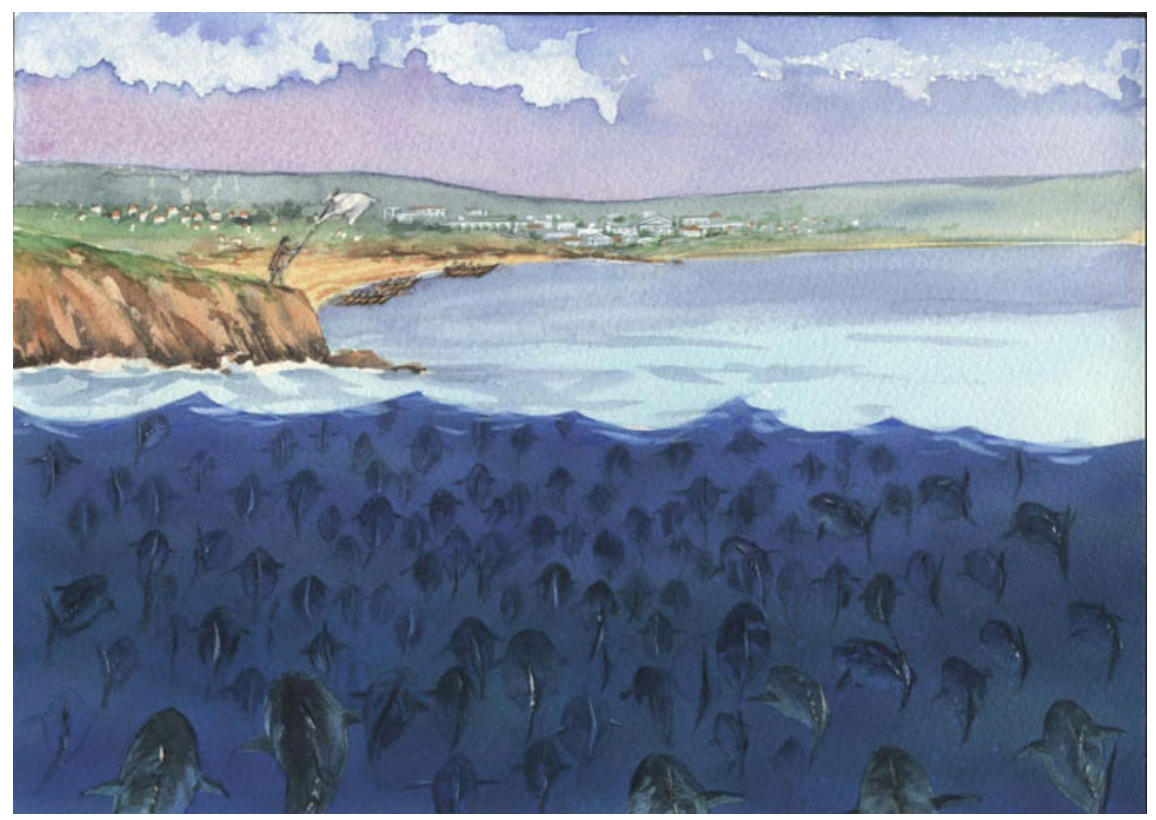

Fig. 4.8 Sighting of a bluefin tuna bank from the cape of Baelo Claudia An interpretation by Cort (2006, 2007) Artist: Lineke Zubieta (Santander, Spain) (Documentary file, IEO)

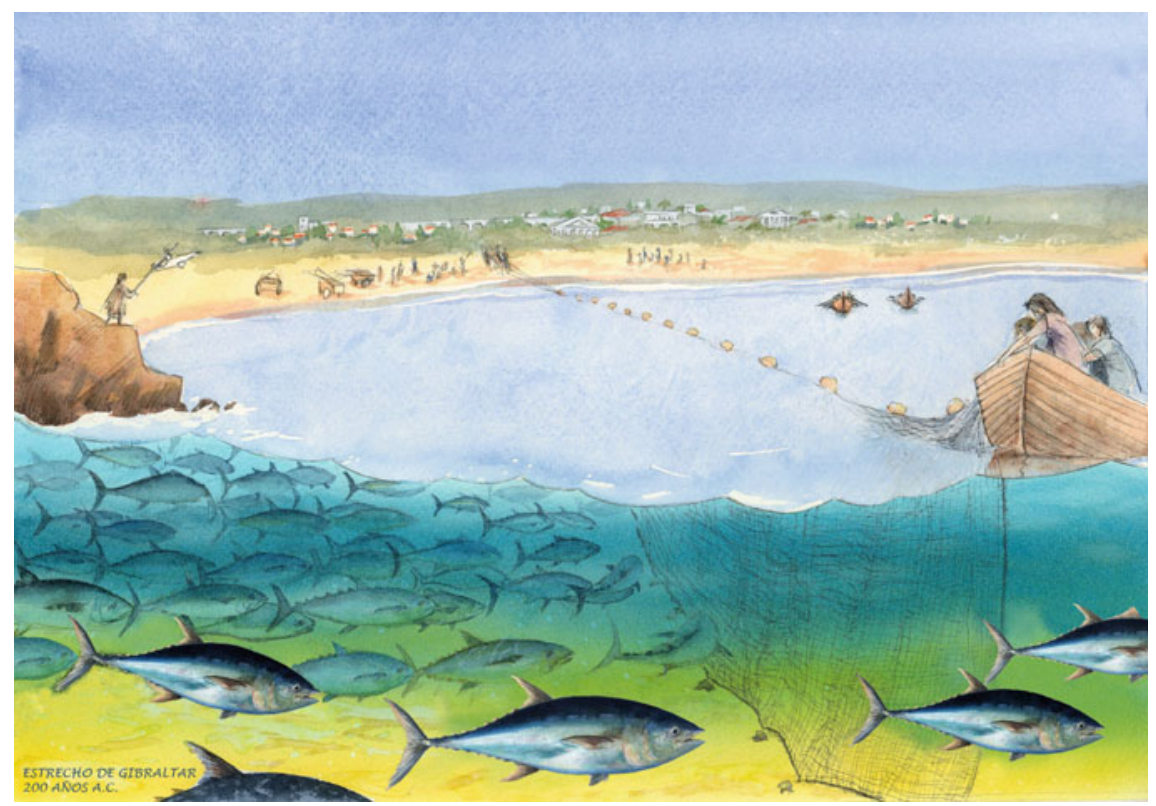

Fig. 4.9 Bluefin tuna fishing in the Roman city of Baelo Claudia, 2nd century B.C. An interpretation by Cort $(2006,2007)$ Artist: Lineke Zubieta (Santander, Spain) (Documentary archive, IEO) 


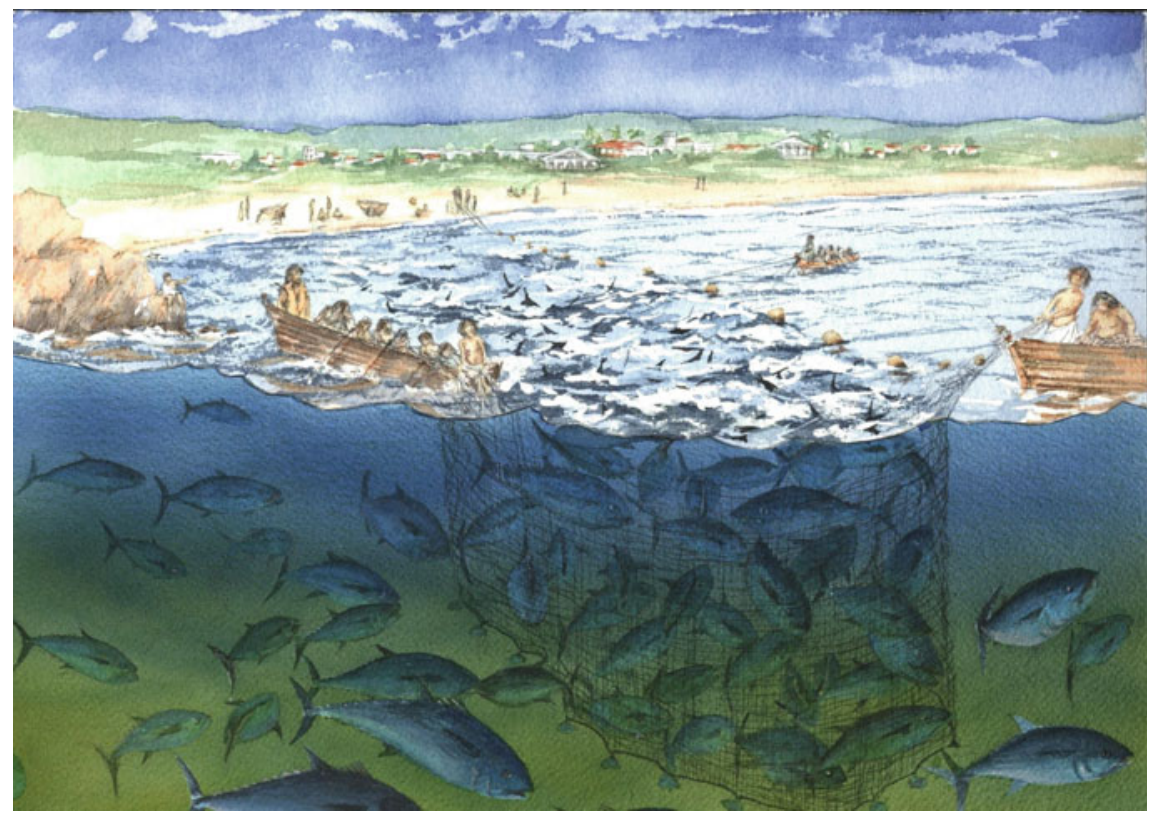

Fig. 4.10 Successful bluefin tuna fishing operation in Baelo Claudia An interpretation by Cort (2006, 2007) Artist: Lineke Zubieta (Santander, Spain)

\subsection{Modern Age}

Regarding the Modern Age there are many testimonies to the traps (Fig. 4.11) being a privilege awarded by the kings to the nobility (García 2012). In 1379, King John I recognized the property of all the traps in favor of the Count of Niebla. In 1396, Henry III similarly recognized such property as patrimony of the count's inheritance. In 1445, King John II declared the first Duke of Medina Sidonia as the owner of all space suitable for the setting up of the traps. Centuries later, a document written by the Benedictine father Friar Martín de Sarmiento (Fig. 4.12) addressed to the Duke of Medina Sidonia (López and Ruiz 2005, 2012), then owner of the traps, on the 18th of February 1757, stated that: This observation that I have been witness to excited the curiosity of the Duke upon comparing it with the scarcity of tunas now being caught in the traps; stating that in past centuries the tunas caught in the traps were almost infinite. When father Sarmiento wrote the phrase: ...stating that in past centuries the tunas caught in the traps were almost infinite, he was referring to the historical catches of 1555-1570 in which practically two traps (Conil and Zahara) caught a mean of 58,000 tunas per fishing season, though according to several contemporary scientists (J. M. Fromentin; D. Florido del Corral, J. A, López) this figure would have also included small tunas. Twenty years after those historic events catches hardly reached 5,000 tunas per trap. In the last quarter of the XVIth century the absence of tunas 


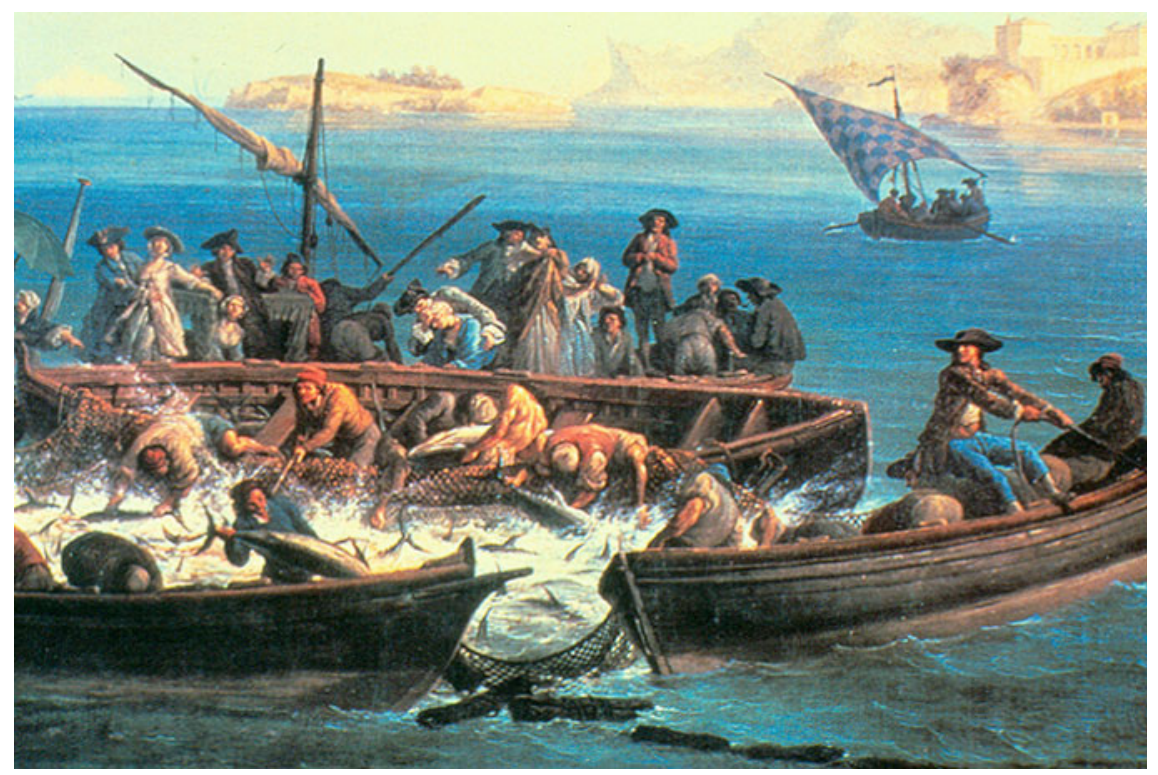

Fig. 4.11 Bluefin tuna fishing with trap in the Strait of Gibraltar, around 1550. Taken from Di Natale (2012)

coincided with the desertion of the market by buyers, which led to the downfall of the traps.

In de Buen (1925) the catch statistics are presented from three Spanish traps installed in the Strait of Gibraltar between 1525 and 1756, in which maximums and minimums are shown between $1555-1570$ and 1590-1756 respectively (Fig. 4.13). Studying this historical series, Gancedo et al. (2009) concluded that the low temperatures recorded between 1640-1715 during the so-called Little Ice Age may have reduced recruitment and the abundance of this species in the North Atlantic and Mediterranean. Sella (1929), cited by Manfrin et al. (2012), was the first to describe the existence of periodic fluctuations of 110 years in the fishing statistics from four traps of the Strait of Gibraltar and western Mediterranean Sea between 1770 and 1925. Later, Fromentin (2002) studied variability in the catches of eight traps in the eastern Atlantic and western Mediterranean between 1599 and 1960 and found periodic fluctuations of 100-120 years, which Ravier and Fromentin (2004) determined to be inversely related to sea temperature, which may have led to variations in ABFT spawning migratory patterns in response to changes in oceanic conditions.

\subsection{Recent History}

Until a little earlier than the middle of the XXth century the most important ABFT catches in the eastern part of the Atlantic ocean and Mediterranean sea were made 


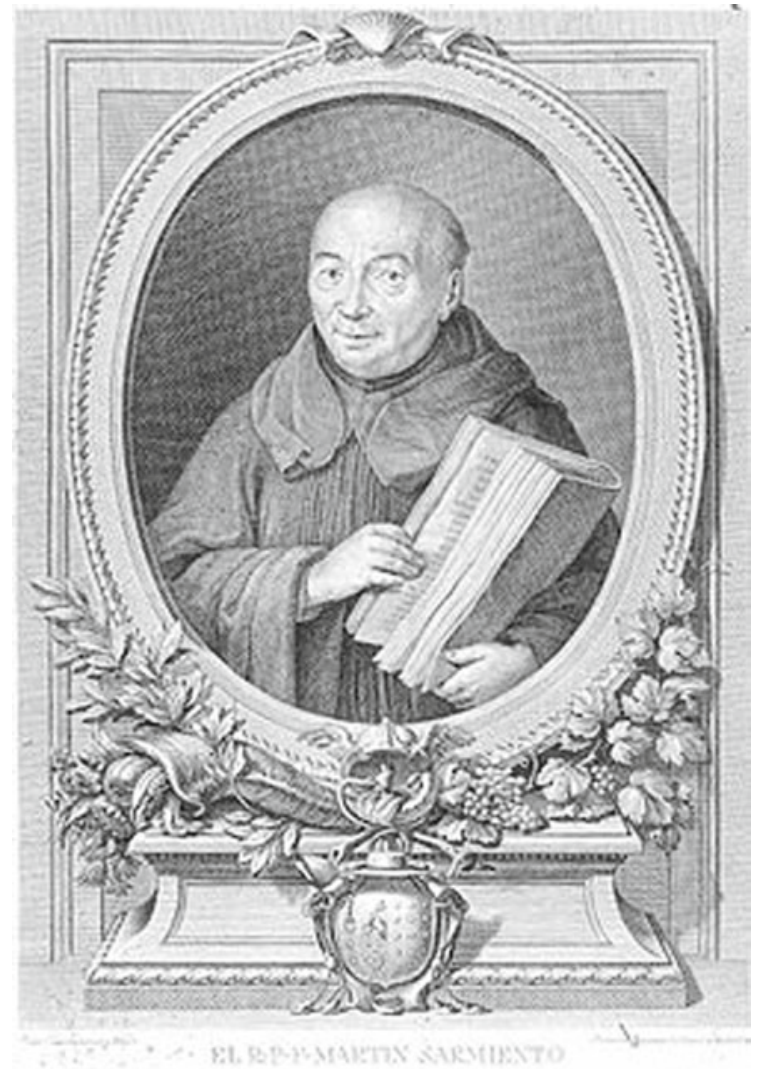

Fig. 4.12 Father Martín de Sarmiento (1695-1772). (Taken from García 2012)

mainly by traps, and it was from then onwards that other fishing systems began to be used, such as purse seine, longline and bait boat (ICCAT 2010). This new era created a bonanza situation that hardly lasted 10 years, because from 1963 there came a sharp fall in catches in the ABFT spawner fisheries of the eastern Atlantic, the Strait de Gibraltar and northern European fisheries (Fromentin and Powers 2005), so much so that the traps have since failed to return to the production levels they had reached during the first half of the last century (Cort et al. 2012) and the ABFT fisheries of the north of Europe collapsed at the beginning of the 1980s (Nøttestad and Graham 2004; Bennema 2018). In the same way, the groups of small spawners (up to $2 \mathrm{~m}$ ), which had been abundant in the Bay of Biscay, were no longer so after 1973 (Cort and Nøttestad 2007). In a study recently published (Cort and Abaunza 2015) the relationship is studied between the high fishing mortality exerted on juveniles ( $<5$ years) in the eastern Atlantic juvenile fisheries from 1949 to 2006, with the decline in the catch of ABFT spawners. At the start of this crisis there was no international organization dedicated to monitoring and management over tuna fisheries resources in the Atlantic and Mediterranean, since ICCAT was founded in 1966. 


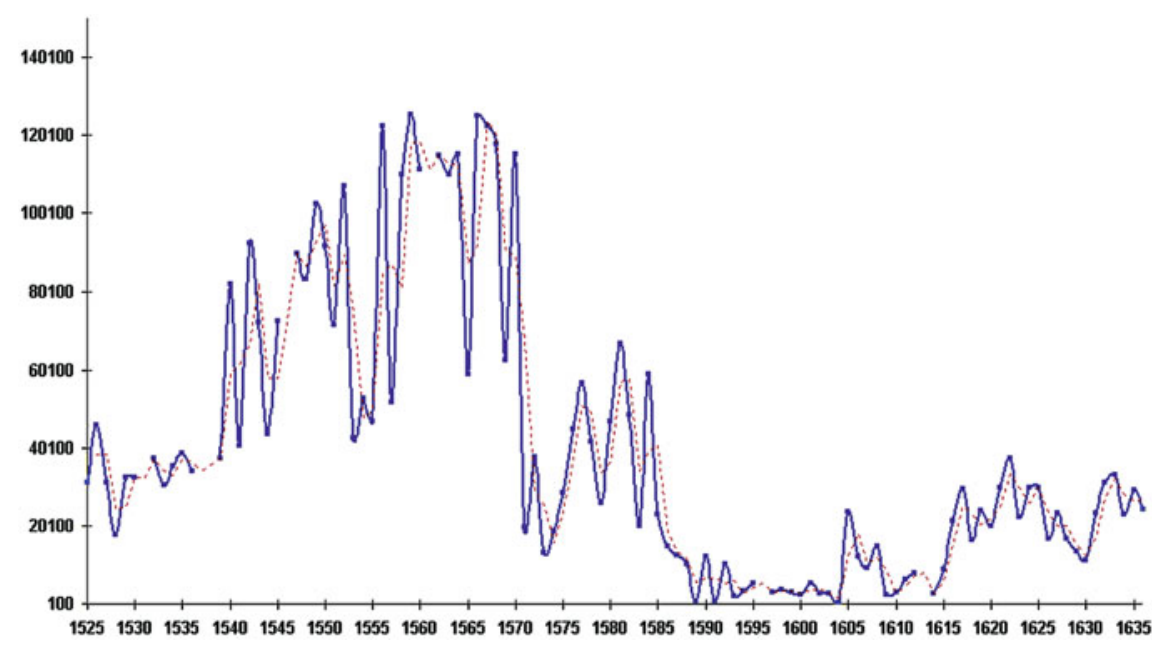

Fig. 4.13 Tuna catches (in number of fishes) of three Spanish traps (Conil, Zahara and Conilejo) between 1525 and 1635 (The dashed line is the moving mean for a period of two years)

The history of the eastern ABFT fishing in the last seventy years is plagued with events that have shaped the destiny of this species. The first of these was the collapse of the northern European fisheries at the beginning of the 1980s and the sharp fall in the catches of the traps which brought with the disappearance of the Tuna Trap Fishing National Consortium (1928-1971) ten years later (Ríos 2007; López and Ruíz 2012; Florido del Corral 2013; Florido del Corral et al. 2018). Whereas Atlantic traps fisheries survived from the 1980s thanks to the entrance of the Japanese market into the sector, pressure on stocks by the purse seine fleets rose alarmingly in the Mediterranean from the 1970s leading, thirty years later, to the greatest crisis in the history of this fishery, and in turn forcing the adoption of the PARP by ICCAT in 2007. The rigorous monitoring of the fishery since then, the implementation of severe conservation measures and highly restrictive fishing quotas, which have led to the disappearance of a large part of the fleet as well as an increase in scientific activities (Di Natale et al. 2017), including aquaculture (De la Gándara et al. 2016), have turned this fishery into a world-class example of population recovery, as described in the latest reports of the scientific committee of ICCAT, the SCRS (ICCAT 2017).

\section{References}

Allen JRM, Brandt U, Brauer A, Hubberten H-W, Huntley B, Keller J, Kraml M, Mackensen A, Mingram J, Negendank JFW, Nowaczyk NR, Oberhänsli H, Watts WA, Zolitschka B (1999) Rapid environmental changes in southern Europe during the last glacial period. Nature 400:740-743 
Aranegui C (2008) Introducción a la arqueología de Lixus (Larache, Marruecos). Biblioteca virtual Miguel de Cervantes, 19 pp. http://www.cervantesvirtual.com/obra/introduccin-a-la-arqueologade-lixus-larache-marruecos-0/

Arévalo A, Bernal D (2007) Las Cetariae de Baelo Claudia. Avance de las investigaciones arqueológicas en el barrio meridional (2000-2004). Alicia Arévalo y Darío Bernal (Editores científicos). Junta de Andalucía. Consejería de cultura. Universidad de Cádiz, Servicio de publicaciones, 571 pp. ISBN 978-84-9828-155-2

Bennema FP (2018) Long-term occurrence of Atlantic bluefin tuna Thunnus thynnus in the North Sea: contributions of non-fishery data to population studies. Fish Res 199:177-185. https://doi. org/10.1016/j.fishres.2017.11.019

Cort JL (2006) El cimarrón del Atlántico Norte y Mediterráneo. Sexto concurso nacional de Ciencia en Acción. Modalidad, Medioambiente. Cort JL (coordinador). Instituto Español de Oceanografía. Depósito legal: SA. 494-2006, 80 pp.

Cort JL (2007) El enigma del atún rojo reproductor del Atlántico nororiental. Modalidad, Sostenibilidad. Octavo concurso nacional de Ciencia en Acción. José L. Cort (coordinador). Instituto Español de Oceanografía. Depósito legal: SA. 538-2007, 62 pp.

Cort JL, Abaunza P (2015) The fall of tuna traps and collapse of the Atlantic Bluefin Tuna, Thunnus thynnus (L.), fisheries of Northern Europe in the 1960s. Rev Fish Sci Aquac 23(4):346-373. http://dx.doi.org/10.1080/23308249.2015.1079166

Cort JL, de la Serna JM, Velasco M (2012) El peso medio del atún rojo (Thunnus thynnus) capturado por las almadrabas del sur de España entre 1914-2010. Col Vol Sci Pap ICCAT 67:231-241

Cort JL, Nøttestad L (2007) Fisheries of bluefin tuna (Thunnus thynnus) spawners in the Northeast Atlantic. Col Vol Sci Pap ICCAT 60:1328-1344

De Buen F (1925) Biología del atún, Orcinus thynnus (L.). Resultado de las campañas realizadas por acuerdos internacionales, 1 . Madrid, $118 \mathrm{pp}$.

De la Gándara F, Ortega A, Buentello A (2016) Tuna Aquaculture in Europe. In: Benetti DD, Partridge GJ, Buentello A (eds) Advances in tuna aquaculture. From hatchery to market. Academic Press is an imprint of Elsevier. The Boulevard, Langford Lane, Kidlington, Oxford OX5 1 GB 225 Wyman Street, Waltham MA 02451, pp 115-184

Di Natale (2012) New data on the historical distribution of bluefin tuna (Thunnus thynnus, L.) in the Artic Ocean. Col Vol Sci Pap ICCAT 68(1):102-114

Di Natale A, Tensek S, Pagá García A (2017) ICCAT Atlantic-wide research programme for bluefin tuna (GBYP): activity report for the last part of phase 5 and first part of phase 6 (2015-2016). Col Vol Sci Pap ICCAT 73(7):2424-2503

Fernández Gómez F, Yáñez Polo MA, Hurtado Rodríguez L (2007) Surcando el tiempo. A la caza del atún rojo en las almadrabas atlánticas del estrecho. Desde la antigüedad hasta nuestros días. Fluidmecanica Sur, Club UNESCO Sevilla y Tanger. Proyecto Oceanus, 182 pp. ISBN 978-84606-4458-3

Finlayson C, Giles Pacheco F, Rodríguez-Vidal J, Fa JDA, Gutierrez López JM et al (2006) Late survival of Neanderthals at the southernmost extreme of Europe. Nature 443(7113):850-853

Florido del Corral D (2013) Las almadrabas andaluzas bajo el consorcio nacional almadrabero (1928-1971): aspectos socio-culturales y políticos. Semana, Ciencias Sociais e Humanidades 25:117-151. ISSN 1137-9669

Florido del Corral D, Santos A, Ruiz JM, López JA (2018) Las almadrabas suratlánticas andaluzas. Historia, tradición y patrimonio (siglos XVIII-XXI). Editorial Universidad se Sevilla, 328 pp. ISBN 978-84-472-1885-1

Fromentin JM (2002) Final Report of STROMBOLI-EU-DG XIV Project 99/022. European Community-DG XIV, Brussels, 109 pp.

Fromentin JM, Powers J (2005) Atlantic bluefin tuna: population dynamics, ecology, fisheries and management. Fish Fish 6:281-306

Gancedo U, Zorita E, Solari AP, Chust G, Santana del Pino A, Polanco J, Castro JJ (2009) What drove tuna catches between 1525 and 1756 in southern Europe? International Council for the Exploration of the Sea. Published by Oxford Journals: 1595-1604 
García F (2012) Las almadrabas de la costa andaluza bajo el dominio de la casa ducal de Medina Sidonia. Su tipología, sus producciones y sus problemáticas. Col Vol Sci Pap ICCAT 67:75-87

García Vargas E, Bernal D (2009) Roma y la producción de garum y salsamenta en la costa meridional de Hispania. Estado actual de la investigación. In Arqueología de la pesca en el estrecho de Gibraltar. De la prehistoria al fin del mundo antiguo. D. Bernal Casasola (Editor científico). Monografías del Proyecto Sagena 1. Servicio de publicaciones de la Universidad de Cádiz, pp 133-182. ISBN 978-84-9828-234-4

García Vargas E, Florido del Corral D (2011) Tipos, origen y desarrollo histórico de las almadrabas antiguas. Desde época romana al imperio bizantino. In: Pescar con Arte. Fenicios y romanos en el origen de los aparejos andaluces. D. Bernal Casasola (Editor científico). Servicio de publicaciones de la Universidad de Cádiz, pp 231-254. ISBN 978-84-9828-365-5

Giles-Pacheco F, Finalyson C, Gutiérrez JM, Santiago A, Finalyson G, Reinoso C, Giles Guzmán F (2001) Investigaciones arqueológicas en Gorham’s cave (Gibraltar): Resultados preliminares de las campañas de 1977 a 1999. The Gibraltar Caves Project. Ethel Allul/Laboratorio de prehistoria. Universidad Rovira i Virgili, Tarragona. Almoraima, 16 pp.

ICCAT (2010) ICCAT Manual. Description of species. Chapter 2; 2.1.5 Atlantic Bluefin Tuna 99:93-111. Madrid, ICCAT. http://iccat.int/Documents/SCRS/Manual/CH2/2_1_5_BFT_ENG. pdf

ICCAT (2017) Report of the 2017 ICCAT bluefin stock assessment meeting. Madrid, Spain, 22-27 July 2017, 106 pp. http://iccat.int/Documents/Meetings/Docs/2017_BFT_ASS_REP_ENG.pdf

López JA, Ruiz JM (2005) Series históricas de las capturas de atún rojo en las almadrabas del golfo de Cádiz. In Acuicultura, Pesca y Marisqueo en el golfo de Cádiz. Junta de Andalucía, Consejería de Agricultura y Pesca, pp 308-364. http://www.juntadeandalucia.es/servicios/publicaciones/ detalle/48581.html

López JA, Ruíz JM (2012) Series históricas de las capturas de atún rojo en las almadrabas del golfo de Cádiz (siglos XVI-XXI). Col Vol Sci Pap ICCAT 67:139-174

Manfrin G, Mangano A, Piccinetti C, Piccinetti R (2012) Les données sur la capture des thons par les madragues dans 1’archive du prof. Sella. Col Vol Sci Pap ICCAT 67:106-111

Montero J, Bernal D (2011) El estrecho de Gibraltar en el Pleistoceno. In Benzú y los orígenes de Ceuta. In: Ramos J, Bernal D, Cabral A, Vijante E, Cantillo JJ (coordinadores). Ciudad autónoma de Ceuta, Consejería de educación, cultura y mujer. Museo de la Basílica Tardorromana de Ceuta, Universidad de Cadiz, pp 130-131. ISBN 978-84-15243-14-4

Morales A, Roselló E (2007) Los atunes de Baelo Claudia y Punta Caraminal. In Las Cetariae de Baelo Claudia. Avance de las investigaciones arqueológicas en el barrio meridional (2000-2004). Alicia Arévalo y Darío Bernal (Editores científicos). Junta de Andalucía. Consejería de cultura. Universidad de Cádiz, servicio de publicaciones, pp 489-498. ISBN 978-84-9828-155-2

Niveau de Villedary AM (2009) Ofrendas, banquetes y libaciones. El ritual funerario en la necrópolis púnica de Cádiz. Spal Monografías XII. Servivio de publicaciones, Universidad de Cádiz (ISBN 978-84-9828-258-0). Secretariado de publicaciones, Universidad de Sevilla (ISBN 978-84-4721203-3), 297 pp.

Niveau de Villedary AM (2011) Algunos indicios sobre la (posible) práctica de sacrificios humanos en Cádiz. In Cultos y ritos en la Gadir fenicia. Servivio de publicaciones, Universidad de Cádiz (ISBN 978-84-9828-337-2). Secretariado de publicaciones, Universidad de Sevilla (ISBN 97884-472-1343-6), pp 405-420

Nøttestad L, Graham N (2004) Preliminary overview of the Norwegian fishery and science on Atlantic bluefin tuna (Thunnus thynnus). Scientific report from Norway to ICCAT Commission meeting in New Orleans, USA, 15-21 Nov 2004, 12 pp.

Ponsich M (1988) Aceite de oliva y salazones de pescado. Factores geo-económicos de Bética y Tingitania. Editorial Universidad Complutense, 253 pp. ISBN-84-7491-248-2

Ravier C, Fromentin JM (2004) Are long-term fluctuations in Atlantic bluefin tuna (Thunnus thyn$n u s)$ populations related to environmental changes? Fish Oceanogr 13:145-160

Ríos Jiménez S (2007) La gran empresa almadrabero conservera andaluza entre 1919 y 1936: el nacimiento del Consorcio Nacional Almadrabero. Historia Agraria 41:57-82 
Rodríguez-Vidal J, Finlayson G, Finlayson C, Negro JJ, Cáceres LM, Fa DA, Carrión JS (2013) Undrowning a lost word-the marine isotope stage 3 landscape of Gibraltar. Geomorphology 203:105-114. http://www.elsevier.com/locate/geomorph

Sarà R (1998) Dal mito all'aliscafo. Storie di Tonni e Tonnare. Banca Aegusea Ed., FavignanaPalermo, pp 1-271

Sella M (1929) Migrazioni e habitat del tonno (Thunnus thynnus) studiati col metodo degli ami, con osservazioni ull'accrescimento, sul regime delle tonnare, ecc. Memorie, R. Comitato Talassografico Italiano 159:1-24

Stringer CB, Finlayson JC, Barton RNE, Fernández-Jalbo Y, Cáceres I, Sabin RC, Rhodes EJ, Currant AP, Rodríguez-Vidal J, Giles-Pacheco F, Riquelme-Cantal JA (2008) Neanderthal exploitation of marine mammals in Gibraltar. Proc Natl Acad Sci 105(38):14319-14324

Tzedakis P, Lawson IT, Frogley MR, Hewit GM, Preece RC (2002) Buffered tree population changes in a quaternary refugium: evolutionary implications. Science 297:2044-2047

Open Access This chapter is licensed under the terms of the Creative Commons Attribution 4.0 International License (http://creativecommons.org/licenses/by/4.0/), which permits use, sharing, adaptation, distribution and reproduction in any medium or format, as long as you give appropriate credit to the original author(s) and the source, provide a link to the Creative Commons license and indicate if changes were made.

The images or other third party material in this chapter are included in the chapter's Creative Commons license, unless indicated otherwise in a credit line to the material. If material is not included in the chapter's Creative Commons license and your intended use is not permitted by statutory regulation or exceeds the permitted use, you will need to obtain permission directly from the copyright holder. 